\title{
Assessment of the Mineralization Processes of Potable Natural Mineral Water Using the Chemical Thermodynamics Analysis
}

\author{
Fanmeng Kong*, Yiguo Xue**, Daohong Qiu, Maoxin Su, \\ Huimin Gong, Xintong Wang \\ Geotechnical and Structural Engineering Research Center, Shandong University, Jinan 250061, China
}

Received: 14 September 2020

Accepted: 2 July 2021

\begin{abstract}
To study the mineralization process of potable natural mineral water, this paper collected water samples from the Caowang town in northern China. The hydrochemical characteristics of water samples were determined by the hydrochemical analysis. The results indicate that sampled groundwater is desirable for drinking and two main groundwater types i.e., $\mathrm{Na} \cdot \mathrm{Ca} \cdot \mathrm{Mg}-\mathrm{HCO}_{3}$ and $\mathrm{Na}-\mathrm{HCO}_{3}$ type were found in the study area. Chemical components in groundwater are governed by water-rock interactions and two beneficial chemical components including metasilicic acid and strontium are measured up to the standard values of potable natural mineral water. The chemical thermodynamics analysis was subsequently pioneered to assess the origins of minerals in potable natural mineral water. It can be concluded that metasilicic acid is attributed to the dissolution of feldspar rather than quartz minerals. The increase of strontium originates from the dissolution of strontium carbonate in the recharge area. The Gibbs function is valid and effective for identifying the origins of minerals and assessing the mineralization process of potable natural mineral water. This study can provide insight into protecting the recharge area and ensure the quality of potable natural mineral water, thereby guiding the management of the precious groundwater resource.
\end{abstract}

Keywords: potable natural mineral water, chemical thermodynamics analysis, mineralization process, metasilicic acid, strontium

\section{Introduction}

Potable water has been recognized as an essential source for the existence of humanity and civilization [1]. In recent years, increasing environmental pollution has deteriorated the quality of water resources and imposes harmful effects on humans' health as well as the productivity of agriculture [2-4]. People, thus, brought more attention to exploring high-quality potable water resources. As the merits of high quality, pollutionfree and containing beneficial components, the potable natural mineral water has gained extensive attention in recent years.

*e-mail: kongfanmeng@mail.sdu.edu.cn

**e-mail: xieagle@sdu.edu.cn 
As one special type of groundwater (referred to as abundant beneficial mineral components), the hydrochemical characteristics and quality of potable natural mineral water depend on a series of natural factors. Several academics recommended that four main factors were controlling the origins and dynamics of groundwater components, i.e., hydrological processes, aquifer lithology, hydrogeochemical processes and saltwater intrusion [5-7]. Hydrological processes, such as evaporation, precipitation and runoff, could alter groundwater chemical components [8-10]. Also, hydrogeochemical processes, which contained mineral dissolution, ion transfer and exchange, and groundwater residence time, were recognized as the main origins of groundwater chemical components and determined the hydrochemical types [11-13].

Assessing the hydrochemical characteristics and hydrochemical processes of groundwater have received significant attention from academics and practitioners since the 1940s. One of the pioneering studies on this topic was reported by Piper [14], where the trilinear diagram was presented to describe the water chemistry and divided the water into different types; this method was later improved by Durov [15] to remove the inconvenient when dealing with a large volume of data. Based on modifying the Piper diagram and expanding the Durov diagram, Chadha [16] proposed a diagram to classify the natural waters and identify the hydrochemical processes. This diagram could be divided into eight rectangular fields, each of which represented a water category.

Another graphical method has also been developed by academics; for example, Gibbs [17] drew a universally used diagram to evaluate the sources of groundwater chemical constituents, where mechanisms controlling water chemistry were classified as atmospheric precipitation, rock dissolution and evaporation crystallization process. The establishment of the diagrams was based on the analytical chemical data of water samples collected from rain, river, lake and ocean [18]. At present, the graphical methodologies have been referenced by numerous studies for analyzing the hydrochemical characteristics or processes of groundwater [19-21].

Academics have brought attention to using the geochemical method to conduct the groundwater studies; specifically, the environmental isotopes (i.e., ${ }^{18} \mathrm{O},{ }^{2} \mathrm{H}$, and ${ }^{87} \mathrm{Sr} /{ }^{86} \mathrm{Sr}$ ) have been recognized as important indicators for determining the solute sources of groundwater [22]. This recommendation, subsequently, was verified by Cartwright et al. [23] and they concluded that $\mathrm{Cl} / \mathrm{Br}$ ratios and isotopes (i.e., $\mathrm{R}^{36} \mathrm{Cl}$ values, ${ }^{14} \mathrm{C}$ activities and $\delta^{18} \mathrm{O}$ values) were reliable for reflecting the variations in groundwater recharge. Meanwhile, other environmental isotopes or isotope ratios, such as $\delta^{2} \mathrm{H}-\mathrm{H}_{2} \mathrm{O}, \delta^{18} \mathrm{O}-\mathrm{H}_{2} \mathrm{O}, \delta^{15} \mathrm{~N}-\mathrm{NO}_{3}$, $\delta^{18} \mathrm{O}-\mathrm{NO}_{3}, \delta^{11} \mathrm{~B}, \delta^{34} \mathrm{~S}\left(\mathrm{SO}_{4}\right), \delta^{18} \mathrm{O}\left(\mathrm{SO}_{4}\right), \delta^{13} \mathrm{C}, \delta^{2} \mathrm{H},{ }^{3} \mathrm{H},{ }^{14} \mathrm{C}$, $\delta^{34} \mathrm{~S}$ as well as ${ }^{37} \mathrm{Cl} /{ }^{35} \mathrm{Cl}, \mathrm{Ca} / \mathrm{Sr}, \mathrm{Ge} / \mathrm{Si}$, have also been used to assess the component, salinity or pollution sources of groundwater [24-26]. Moreover, geochemical modeling is another critical method to identify the origins of the chemical components of groundwater; and this method has been referenced by numerous studies, such as Ortega-Guerrero [27], Helstrup et al. [28], Nassery and Kayhomayoon [29], Ledesma-Ruiz et al. [30] and Liu et al. [31].

To manage the groundwater resources, Oregon Department of Environmental Quality proposed the Water Quality Index (WQI) which has been recognized as an effective method to assess the groundwater quality [32-34]. The hydrogeochemical parameters for determining WQI were subsequently discussed by several academics [35, 36]. Meanwhile, the WQI method has been widely exerted by combing geographic information system (GIS) technique [37-39]. Additionally, the statistical model has been extensively recognized as another critical method for assessing the groundwater quality, where the multiple regression equation was established for correlating water quality to chemical variables or environmental properties [4042]. Meanwhile, the mathematical model was conceived as an effective tool that can be used to evaluate the quality of the groundwater or elucidate the permeability of aquifer, such as principle component analysis or Bayesian framework [43-45].

As one special type of groundwater, potable natural mineral water contains a certain amount of minerals, microelements and gases. This highquality groundwater is of great value for human's health and has the functions of hydrotherapy, health care and preservation. For example, the strontium is an indispensable element for skeletal development; and can also add fuel to the prevention and cure of cardiovascular disease. In the context of strong market demand, it is important to assess the water quality and understand the origins of minerals, which can offer a scientific basis for exploring and utilizing the potable natural mineral water resources.

In the previous studies, numerous methods have been explored and used to evaluate the hydrochemical process of groundwater, which effectively revealed the solute sources. However, the widely used environmental isotopes or isotope ratios cannot be used for determining the origins of minerals in groundwater, e.g., the most common metasilicic acid. Also, the mineralization processes of minerals in potable natural mineral water are quite poorly explained by existing models.

Most chemical compositions derive from the rock dissolution reaction. But, minerals are generally insoluble in water, such as quartz and feldspar. It is necessary to evaluate whether the water-rock reactions can happen spontaneously, and then groundwater mineralization processes can be exhibited. In the chemical thermodynamics theory, Gibbs function has been inducted to judge the direction of the chemical reaction. This paper, thus, taking the Caowang town in northern China as a study case, will pioneer the use of chemical thermodynamics methodology that assessing 


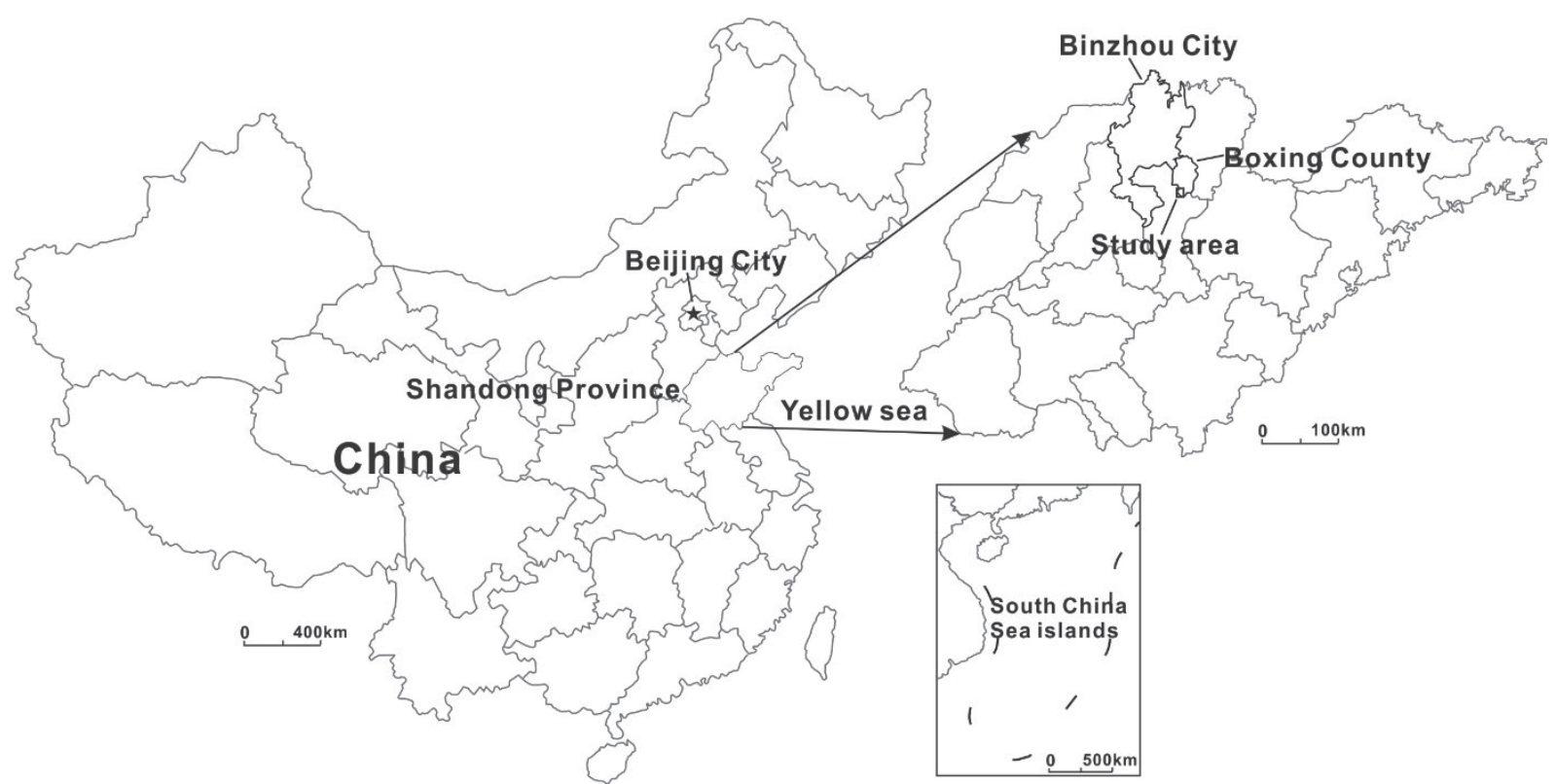

Fig. 1. The location of the study site.

the mineralization process of potable natural mineral water.

Towards this goal, several groundwater samples were first collected throughout the study area. Then, a series of hydrochemical index including $\mathrm{PH}$, temperature, radioactivity, total dissolved solids (TDS), concentrations of cations and anions, etc., were measured in the site and laboratory, followed by the water quality evaluation using the data of hydrochemical analysis. Moreover, to understand the mineralization process of minerals in potable natural mineral water, graphical methods were used to analyze the water types and mechanisms controlling water chemistry. Finally, this paper attempted to use the chemical thermodynamics analysis method to assess the mineralization of potable natural mineral water.

The results of this study can offer a guide for protecting the recharge area and ensure the quality of potable natural mineral water in the study site, thereby guiding the management of the special groundwater resource. Moreover, these proposed research discoveries can be extended to the area with a similar hydrogeological setting. Understanding the mineralization process can provide insight into the reasonable exploitation and utilization of potable natural mineral water resources; and also helps to minimize the risk of resource exploitation and gain significant economic, social and environmental benefits.

\section{Materials and Methods}

\section{Groundwater Sampling Sites}

The study area shown in Fig. 1 comprises the entire Caowang town located in the south of Boxing County,
Binzhou City, Shandong Province, in northern China and occupies approximately $56 \mathrm{~km}^{2}$. This study region includes 27 villages and extends from North latitudes $36^{\circ} 57^{\prime}$ to $37^{\circ} 04^{\prime}$, and East longitudes $118^{\circ} 07^{\prime}$ to $118^{\circ} 13^{\prime}$. The area belongs within the south of Lubei plain with elevations of 7-9 $\mathrm{m}$.

The climate in the study site is temperate continental monsoon climate, with the annual average

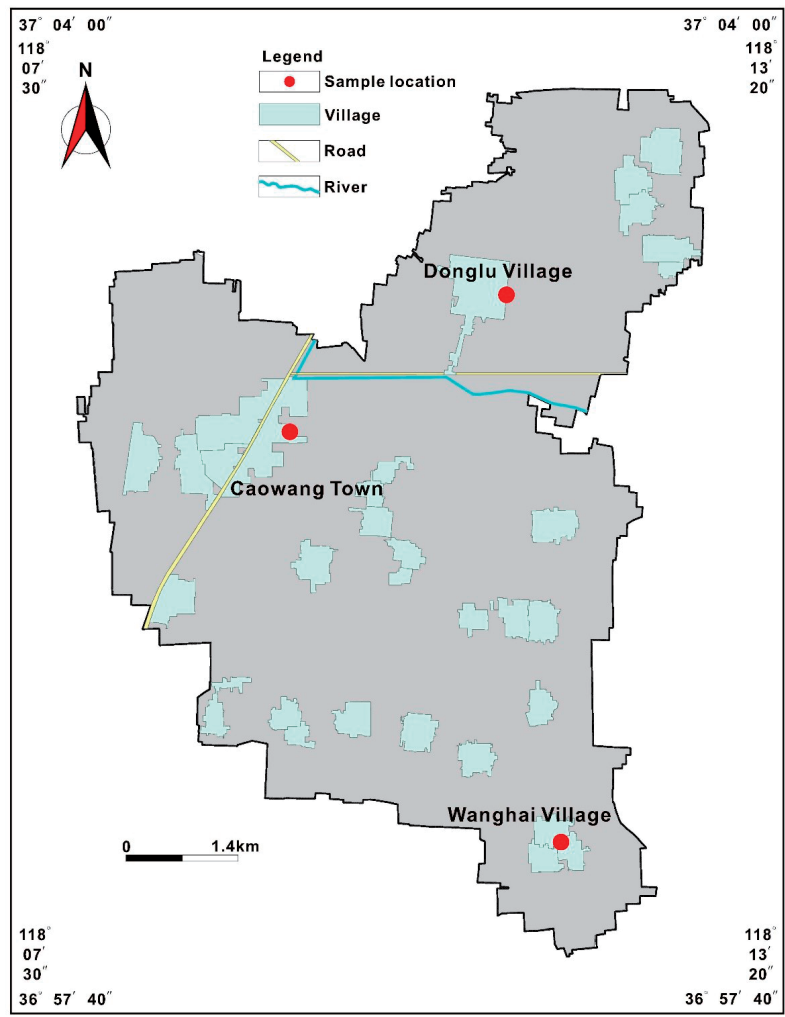

Fig. 2. Distributions of samples collected in this paper. 
temperature and annual average precipitation of $12.6^{\circ} \mathrm{C}$ and $586.6 \mathrm{~mm}$, respectively (10 years from 2008 to 2018). The precipitation is controlled by the Asian summer monsoon dominantly and $64 \%$ of the annual rainfall occurs between June and August. The annual evaporation, simultaneously, is $1119.6 \mathrm{~mm}$, which is nearly two times higher than the average annual precipitation. Also, the mean annual relative humidity during the period is about $69 \%$. The Yubei River shown in Fig. 2 is the main river in the study area and its water flow rate fluctuates seasonally. This river is recognized as the critical drainage channel for flood and as the main source of irrigation for farmland.
The geology of the study area was depicted in Fig. 3. It can be seen that Quaternary deposits, which comprises of argillaceous sand, silt or fine-medium grained sand, sandy clay and sand-gravel, cover the entire study site. Exploratory investigations including geophysics survey and hydrogeologic drilling indicated that the aquifers of this area situate in detrital deposits of Paleogene, Neogene and Quaternary ages. The Paleogene rocks include sandstone and mudstone, which were observed in the north of Qihe-Guangrao fault (see Fig 3). The Neogene rocks which were known as sandstone, mudstone and caliche nodule existed in the south of the study area. This strata unit unconformably
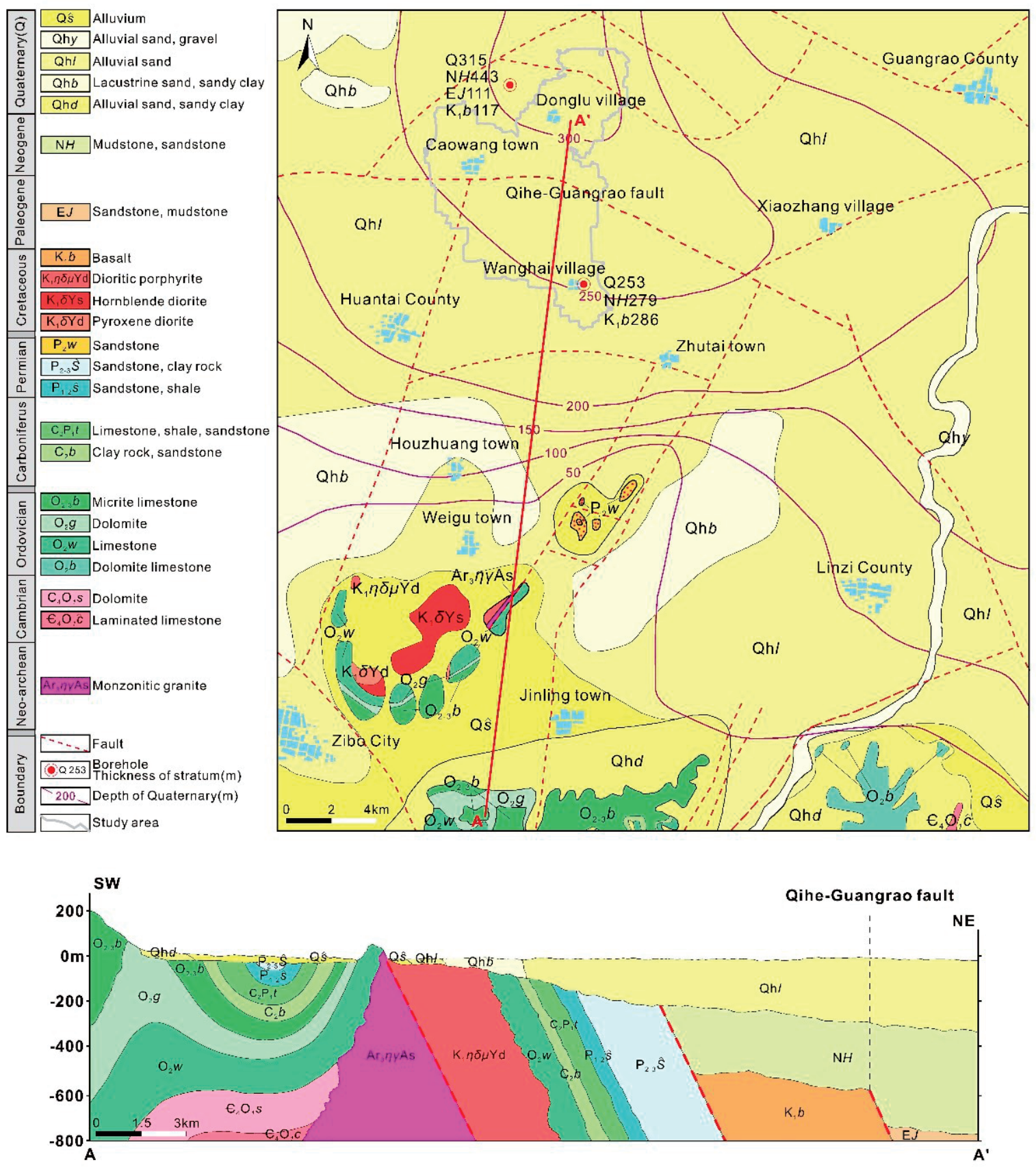

Fig. 3. The recharge area and flow path of potable natural mineral water in the study area. 
overlies the Cretaceous basalt or Paleogene rocks and has a thickness ranging from 300 to $430 \mathrm{~m}$.

Based on geophysical explorations and the data collected from boreholes, the Quaternary aquifer is regarded as the unconfined and multilayer aquifer while the Neogene and Paleogene aquifers are confined and multilayer aquifers simultaneously. Concerning the hydrogeology of the study area, the permeability of the Quaternary aquifer varies evidently since the distributions of sand and gravel are different in the various sites of the area. Also, this aquifer is recharged by precipitation, irrigation and rivers. Based on the pumping test data, the depth of groundwater level fluctuates from 5 to $20 \mathrm{~m}$ and gushing water flux is $800 \mathrm{~m}^{3} / \mathrm{d}$. While Neogene and Paleogene confined aquifers are replenished by the groundwater runoff and groundwater level varies regularly depending on the wet and dry seasons in the recharge area. Transmissivity of sandstone aquifer varies since the heterogeneous of rocks derived from bedding, fractures or grain size. The transmissivity value of the Neogene confined aquifer is about $23 \mathrm{~m}^{2} / \mathrm{d}$ and the gushing water flux ranges from 600 to $870 \mathrm{~m}^{3} / \mathrm{d}$.

\section{Sampling Procedure and Laboratory Testing Methods}

A total of 18 groundwater samples were collected from observation boreholes with depth varying from 230 to $530 \mathrm{~m}$ (referred to the confined sandstone aquifer). As seen in Fig. 2, sample locations including Wanghai village (12 samples), center of Caowang town (3 samples) and Donglu village (3 samples) were widespread over the study site. Polyethene plastic bottles were used to collect water samples. Observation boreholes were rinsed by pumping water for several

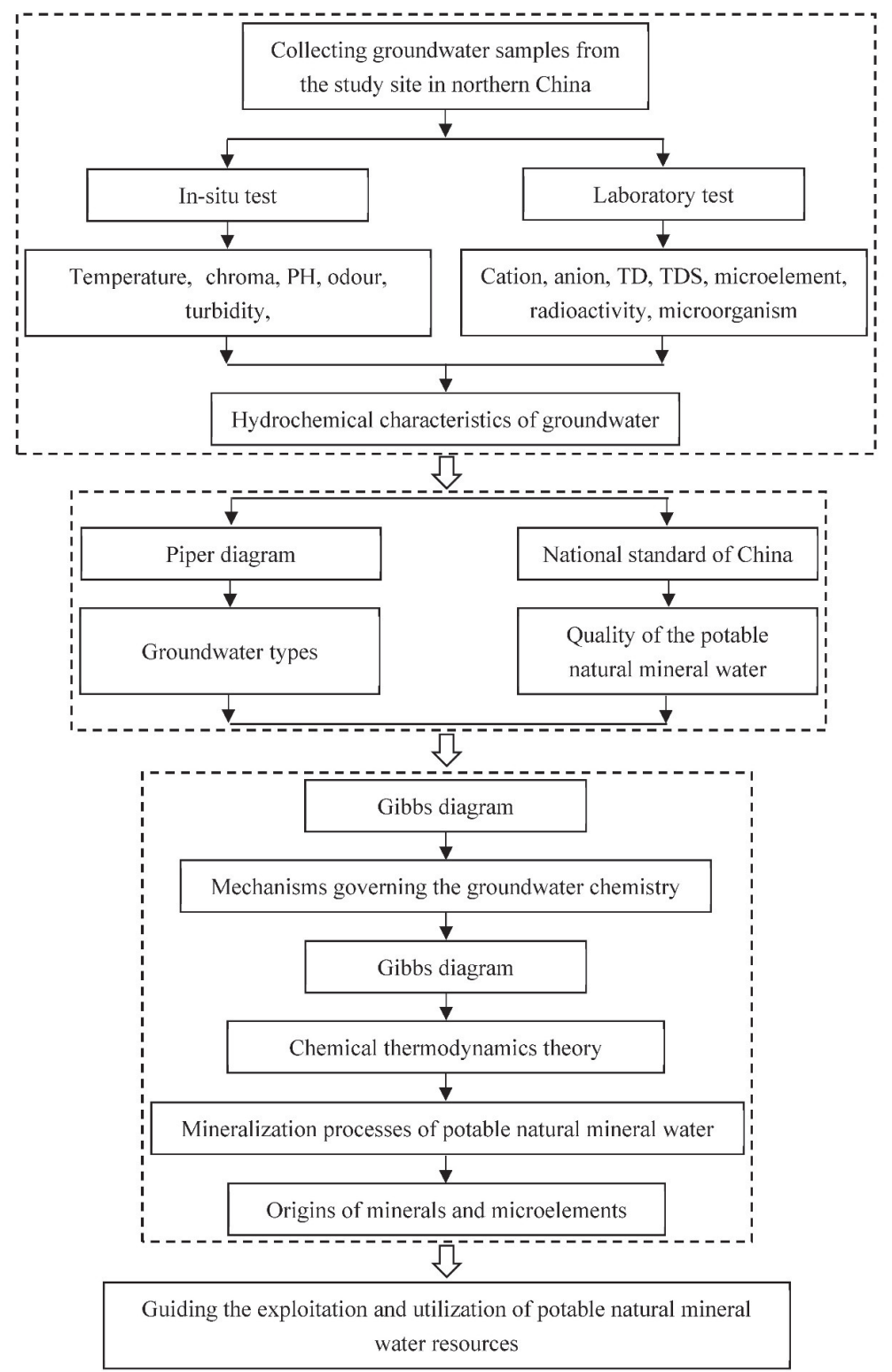

Fig. 4. The flow chart of methods used in this study. 
hours and sample bottles were washed with sample water prior to collection. Then, the groundwater samples were studied using methodologies including insitu and laboratory tests, hydrochemical analysis and chemical thermodynamics analysis (see Fig. 4).

Parameters including water temperature, chroma, odour, turbidity and $\mathrm{PH}$ were determined in situ. Subsequently, parameters such as major cations, anions, total hardness (TD), TDS, microelements, radioactivity and microorganisms were measured in four laboratories including MLR (Ministry of Land and Resources) Jinan Mineral Resources Supervision and Testing Center, MLR Groundwater and Environment Supervision and Testing Center, Shandong Geological Environment Monitoring Station Testing Center and Shandong Provincial Analysis and Test Center.

In the laboratory, carbonate and bicarbonate were measured against the titration method. Major cations e.g., potassium $\left(\mathrm{K}^{+}\right)$, sodium $\left(\mathrm{Na}^{+}\right)$, calcium $\left(\mathrm{Ca}^{2+}\right)$, magnesium $\left(\mathrm{Mg}^{2+}\right)$ were analyzed with an atomic fluorescence spectrophotometer (AFS-820), while anions including chloride $\left(\mathrm{Cl}^{-}\right)$, bicarbonate $\left(\mathrm{HCO}_{3}^{-}\right)$, sulfate $\left(\mathrm{SO}_{4}{ }^{2-}\right)$, nitrate $\left(\mathrm{NO}_{3}^{-}\right)$were determined by ion chromatography (ICS-90, Dionex), The TD and TDS were measured using the dry-weight method and titration method respectively. Microelements, such as lithium (Li), strontium (Sr), zinc ( $\mathrm{Zn})$, selenium (Se), and iodine (I), were tested with the plasma atomic emission spectrometer (ICAP6300 or IRIS Intrepid) and the radioactivity ( $\beta$ and ${ }^{226} \mathrm{Ra}$ ) were calculated using the low background measurement apparatus. Microorganisms (e.g. coliform, streptococcus faecium, pseudomonas aeruginosa and perfringens) were determined with the filter membrane method. All laboratory tests were performed based on the standard methods of NHFPC (National Health and Family Planning Commission of China) and CFDA (China Food and Drug
Administration [46]. The summary of major chemical parameters acquired from the groundwater samples was listed in Table 1.

\section{Results and Discussion}

\section{Hydrochemical Characteristics of Sampled Groundwater}

As shown in Table 1, groundwater samples possess an average $\mathrm{PH}$ value of 7.62 and fluctuate between 7.52 and 7.68, which indicates that groundwater in the study site is slight alkaline nature and between the maximum permissible limits of WHO (World Health Organization) standards. The slight alkalinity maybe because of the bicarbonate ions, which derived from the free combination of $\mathrm{CO}_{2}$ with water. The TDS ranges from 366.11 to $554.89 \mathrm{mg} / \mathrm{L}$ and hardness has a scope of 211.83 to $261.40 \mathrm{mg} / \mathrm{L}$. High TDS magnitude results from the leaching of salts from soil or anthropogenic activities. The domestics' sewage may percolate into the groundwater, which can result in a rapid increasing of TDS concentration. TDS has been recognized as an important reference for ascertaining the suitability of groundwater of any purposes. Groundwater in the study site is desirable for drinking according to the limit of TDS $(1000 \mathrm{mg} / \mathrm{L})$ suggested by MOHC (Ministry of health of China) and SAC (Standardization Administration of China) [47].

The concentrations of cation illustrate a tendency of $\mathrm{Ca}^{2+}>\mathrm{Na}^{+}>\mathrm{Mg}^{2+}>\mathrm{K}^{+}$and concentrations fluctuated from 51.67 to $64.64,26.32$ to $71.91,20.12$ to 24.30 and 1.75 to $2.07 \mathrm{mg} / \mathrm{L}$, respectively. The groundwater, thus, possesses the Ca-rich property rather than Na-rich property, which indicates that the chemical composition

Table 1. Summary of analyzed chemical parameters of groundwater samples.

\begin{tabular}{|c|c|c|c|c|c|}
\hline Parameter & Unit & Wanghai village samples & Caowang town samples & Donglu village samples & Mean values \\
\hline $\mathrm{PH}$ & - & 7.68 & 7.66 & 7.52 & 7.62 \\
\hline $\mathrm{TDS}$ & $\mathrm{mg} / \mathrm{L}$ & 554.89 & 366.11 & 388.01 & 436.34 \\
\hline $\mathrm{K}^{+}$ & $\mathrm{mg} / \mathrm{L}$ & 2.07 & 1.75 & 1.88 & 1.90 \\
\hline $\mathrm{Na}^{+}$ & $\mathrm{mg} / \mathrm{L}$ & 71.91 & 26.32 & 41.04 & 46.42 \\
\hline $\mathrm{Ca}^{2+}$ & $\mathrm{mg} / \mathrm{L}$ & 51.67 & 64.64 & 63.19 & 59.83 \\
\hline $\mathrm{Mg}^{2+}$ & $\mathrm{mg} / \mathrm{L}$ & 20.12 & 24.30 & 23.98 & 22.80 \\
\hline $\mathrm{Cl}^{-}$ & $\mathrm{mg} / \mathrm{L}$ & 26.50 & 14.58 & 316.80 & 19.46 \\
\hline $\mathrm{HCO}_{3}^{-}$ & $\mathrm{mg} / \mathrm{L}$ & 316.37 & 326.54 & 51.99 & 319.90 \\
\hline $\mathrm{SO}_{4}^{2-}$ & $\mathrm{mg} / \mathrm{L}$ & 63.86 & 40.17 & 5.06 & 52.00 \\
\hline $\mathrm{NO}_{3}^{-}$ & $\mathrm{mg} / \mathrm{L}$ & 4.57 & 4.68 & 256.55 & 4.77 \\
\hline $\mathrm{TD}^{-}\left(\mathrm{CaCO}_{3}\right)$ & $\mathrm{mg} / \mathrm{L}$ & 211.83 & 261.40 & & 243.26 \\
\hline
\end{tabular}

Note: Each column lists the mean values for chemical parameters of each water sample 
of water is controlled by the rock weathering. The concentration of $\mathrm{Ca}^{2+}$ and $\mathrm{Mg}^{2+}$ originate from leaching of carbonate minerals, e.g., calcite or dolomite. While anion possess a trend of $\mathrm{HCO}_{3}>\mathrm{SO}_{4}{ }^{2}>\mathrm{Cl}^{-}>\mathrm{NO}_{3}{ }^{-}$and ranges of concentrations are from 316.37 to 326.54 , 40.17 to $63.86,14.58$ to 26.50 and 4.57 to $5.06 \mathrm{mg} / \mathrm{L}$, respectively. The bicarbonate can not be detected or is in low concentration $(6.39 \mathrm{mg} / \mathrm{L})$. A high concentration of bicarbonate compared with carbonate is due to the dissolution of silicate minerals by soil $\mathrm{CO}_{2}$. Moreover, the sulfate in water may result from the gypsum or other sulfate minerals of sedimentary rocks. Nitrate is hazardous to human health and its concertation of groundwater in study area is lower than the recommended range by $\mathrm{MOHC}$ and SAC [47]. All these hydrochemical data will be subsequently used for assessing the quality and mineralization processes of the potable natural mineral water.

\section{Groundwater Types}

The Piper diagram was a widely used technique for deducing groundwater types. In this paper, the Piper trilinear diagram was depicted to exhibit the concentrations of different ions for individual water samples collected in the study site. Fig. 4 shows that most of the groundwater samples fall into the category of $\mathrm{Na} \cdot \mathrm{Ca} \cdot \mathrm{Mg}-\mathrm{HCO}_{3}$ water type while three groundwater samples (collected in Wanghai village) are classified as the $\mathrm{Na}-\mathrm{HCO}_{3}$ water type. The $\mathrm{Na} \cdot \mathrm{Ca} \cdot \mathrm{Mg}-\mathrm{HCO}_{3}$ water type is likely caused by the dissolution of carbonate minerals, feldspar minerals or silicate minerals, and cation exchange activity. Moreover, the $\mathrm{Na}-\mathrm{HCO}_{3}$ water type is usually due to the dissolution of feldspar minerals and cation exchange activity. A large proportion of the groundwater samples are scattered within zone 5 of the Piper trilinear diagram referred to freshwater with temporary hardness (see Fig. 5). Also, three water samples located in zone 9 represent without dominant ion in the groundwater.

\section{Quality of the Potable Natural Mineral Water}

Potable natural mineral water generally exists in the deep aquifer and refers to the water that contains a certain amount of minerals and microelements, but, no contaminants. The standard method for determining the potable natural mineral water has been published by the AQSIQ (Administration of Quality Supervision, Inspection and Quarantine of China) and SAC (Standardization Administration of China) [48] for many years. A series of index properties including organoleptic properties, beneficial and injurious components, contaminates, as well as microorganisms were standardized and the recommended values were offered for the concentrations of these chemical parameters.

As seen in Table 2, the index properties of groundwater samples, e.g., organoleptic properties and measured concentrations of injurious components, contaminates or microorganisms, are in agreement with the respective standard value following the guidelines

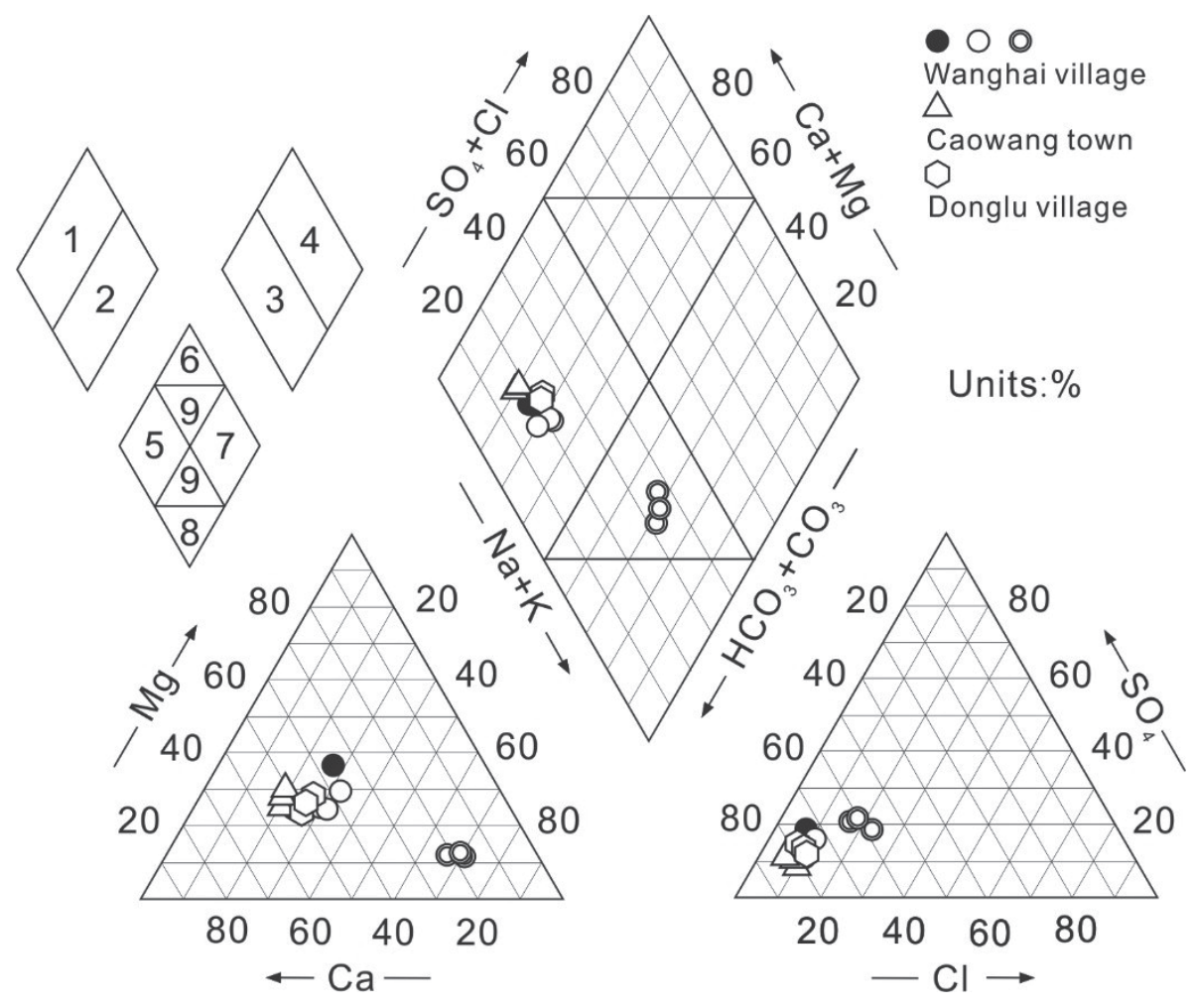

Fig. 5. Piper diagram of groundwater samples. 
Table 2. Summary of analyzed index properties of drinking natural mineral water.

\begin{tabular}{|c|c|c|c|c|c|c|}
\hline Index & Parameter & Unit & $\begin{array}{l}\text { Wanghai village } \\
\text { samples }\end{array}$ & $\begin{array}{c}\text { Caowang town } \\
\text { samples }\end{array}$ & $\begin{array}{c}\text { Donglu village } \\
\text { samples }\end{array}$ & $\begin{array}{c}\text { Standard } \\
\text { values }\end{array}$ \\
\hline \multirow{4}{*}{$\begin{array}{c}\text { Organoleptic } \\
\text { properties }\end{array}$} & Chroma & - & $<5$ & Null & Null & $\leq 15$ \\
\hline & Turbidity & - & $<2$ & $<1$ & $<1$ & $\leq 5$ \\
\hline & Smelly & - & Null & Null & Null & Null \\
\hline & Visible & - & Null & Null & Null & Null \\
\hline \multirow{8}{*}{ Beneficial components } & $\mathrm{Li}$ & $\mathrm{mg} / \mathrm{L}$ & 0.02 & 0.02 & $<0.02$ & $\geq 0.20$ \\
\hline & $\mathrm{Sr}$ & $\mathrm{mg} / \mathrm{L}$ & 0.41 & 0.44 & 0.47 & $\geq 0.20$ \\
\hline & $\mathrm{Zn}$ & $\mathrm{mg} / \mathrm{L}$ & $<0.05$ & $<0.05$ & $<0.05$ & $\geq 0.20$ \\
\hline & I & $\mathrm{mg} / \mathrm{L}$ & $<0.1$ & $<0.05$ & $<0.05$ & $\geq 0.20$ \\
\hline & $\mathrm{H}_{2} \mathrm{SiO}_{3}$ & $\mathrm{mg} / \mathrm{L}$ & 29.65 & 33.82 & 32.13 & $\geq 25.0$ \\
\hline & $\mathrm{Se}$ & $\mathrm{mg} / \mathrm{L}$ & $<0.001$ & $<0.0005$ & $<0.0005$ & $\geq 0.01$ \\
\hline & Free $\mathrm{CO}_{2}$ & $\mathrm{mg} / \mathrm{L}$ & 7.60 & 4.74 & 6.31 & $\geq 250$ \\
\hline & TDS & $\mathrm{mg} / \mathrm{L}$ & 570.46 & 366.11 & 388.01 & $\geq 1000$ \\
\hline \multirow{15}{*}{ Injurious components } & Antimony (Sb) & $\mathrm{mg} / \mathrm{L}$ & $<0.005$ & $<0.001$ & $<0.001$ & $<0.005$ \\
\hline & Arsenic (As) & $\mathrm{mg} / \mathrm{L}$ & $<0.005$ & $<0.01$ & $<0.01$ & $<0.01$ \\
\hline & Copper $(\mathrm{Cu})$ & $\mathrm{mg} / \mathrm{L}$ & $<0.05$ & $<0.05$ & $<0.05$ & $<1.0$ \\
\hline & Barium $(\mathrm{Ba})$ & $\mathrm{mg} / \mathrm{L}$ & 0.069 & 0.06 & 0.06 & $<0.7$ \\
\hline & Cadmium $(\mathrm{Cd})$ & $\mathrm{mg} / \mathrm{L}$ & $<0.0025$ & $<0.001$ & $<0.001$ & $<0.003$ \\
\hline & Chromium (Cr) & $\mathrm{mg} / \mathrm{L}$ & 0.024 & $<0.01$ & $<0.01$ & $<0.05$ \\
\hline & Plumbum $(\mathrm{Pb})$ & $\mathrm{mg} / \mathrm{L}$ & $<0.01$ & $<0.01$ & $<0.01$ & $<0.01$ \\
\hline & Mercury (Hg) & $\mathrm{mg} / \mathrm{L}$ & $<0.00025$ & $<0.00025$ & $<0.00025$ & $<0.001$ \\
\hline & Manganese (Mn) & $\mathrm{mg} / \mathrm{L}$ & 0.008 & $<0.01$ & $<0.01$ & $<0.4$ \\
\hline & Nickel (Ni) & $\mathrm{mg} / \mathrm{L}$ & $<0.02$ & $<0.005$ & $<0.005$ & $<0.02$ \\
\hline & Argentum (Ag) & $\mathrm{mg} / \mathrm{L}$ & $<0.05$ & $<0.01$ & $<0.01$ & $<0.05$ \\
\hline & Bromate $\left(\mathrm{BrO}_{3}^{-}\right)$ & $\mathrm{mg} / \mathrm{L}$ & $<0.01$ & & & $<0.01$ \\
\hline & Borate (B) & $\mathrm{mg} / \mathrm{L}$ & $<0.1$ & 0.07 & 0.09 & $<5.0$ \\
\hline & Fluoride $\left(\mathrm{F}^{-}\right)$ & $\mathrm{mg} / \mathrm{L}$ & 0.33 & 0.28 & 0.29 & $<1.5$ \\
\hline & Oxygen consumption & $\mathrm{mg} / \mathrm{L}$ & 0.72 & 0.21 & 0.21 & $<3.0$ \\
\hline \multirow{7}{*}{ Contaminants } & Phenol & $\mathrm{mg} / \mathrm{L}$ & $<0.002$ & $<0.002$ & $<0.002$ & $<0.002$ \\
\hline & Cyanide $\left(\mathrm{CN}^{-}\right)$ & $\mathrm{mg} / \mathrm{L}$ & $<0.006$ & $<0.002$ & $<0.002$ & $<0.01$ \\
\hline & Anionic detergent & $\mathrm{mg} / \mathrm{L}$ & $<0.05$ & $<0.05$ & $<0.05$ & $<0.3$ \\
\hline & Mineral oil & $\mathrm{mg} / \mathrm{L}$ & $<0.005$ & $<0.005$ & $<0.005$ & $<0.05$ \\
\hline & Nitrite $\left(\mathrm{NO}_{2}^{-}\right)$ & $\mathrm{mg} / \mathrm{L}$ & 0.013 & $<0.002$ & $<0.002$ & $<0.1$ \\
\hline & Radioactivity $\left({ }^{226} \mathrm{Ra}\right)$ & $\mathrm{Bq} / \mathrm{L}$ & 0.0086 & 0.0135 & 0.0111 & $<1.1$ \\
\hline & Radioactivity $(\beta)$ & $\mathrm{Bq} / \mathrm{L}$ & 0.095 & 0.156 & 0.057 & $<1.5$ \\
\hline \multirow{4}{*}{ Microorganisms } & Coliform & - & Null & Null & Null & Null \\
\hline & Streptococcus faecium & - & Null & Null & Null & Null \\
\hline & Pseudomonas aeruginosa & - & Null & Null & Null & Null \\
\hline & Perfringens & - & Null & Null & Null & Null \\
\hline
\end{tabular}

Note: Each column lists the mean values for chemical parameters of each water sample 
from the AQSIQ and SAC [48]. For example, fluoride injurious component in the water has a concentration of $0.3 \mathrm{mg} / \mathrm{L}$ and is lower than the limit concentration $(1.5 \mathrm{mg} / \mathrm{L})$ that causes dental fluorosis. High fluoride concentration may be because the presence of fluoride bearing minerals. As one major artificial pollutant, nitrite in water has concentrations $(<0.013 \mathrm{mg} / \mathrm{L})$ lower than the recommended level $(0.1 \mathrm{mg} / \mathrm{L})$. This contaminant can induce methemoglobinemia through oxidizing the ferrous iron in hemoglobin.

Moreover, the concentration of metasilicic acid $\left(\mathrm{H}_{2} \mathrm{SiO}_{3}\right)$ fluctuates between 29.65 to $33.82 \mathrm{mg} / \mathrm{L}$ while the concentration of $\mathrm{Sr}$ ranges from 0.41 to $0.47 \mathrm{mg} / \mathrm{L}$. The metasilicic acid derives from the dissolution of aluminosilicate minerals such as feldspar. The dissolution of quartz minerals can also generate metasilicic acid, but this water-rock reaction has a very low rate. Metasilicic acid has been demonstrated to play a significant role in alleviating arteriosclerosis, cardiovascular disease and heart disease. Meanwhile, the high concentration of $\mathrm{Sr}$ results from the dissolution of $\mathrm{Sr}$ carbonate bearing in carbonate rocks and this procedure is determined by the $\mathrm{CO}_{2}$ content in water. Orthoclase and anorthite in igneous rock have been recognized as another source of $\mathrm{Sr}$ in groundwater.

It can be concluded that these two beneficial chemical components are measured up to the recommended standard values. The groundwater in the study area (i.e. collected from the confined sandstone aquifer), thus, has excellent water quality and can be recognized as the potable natural mineral water to exploitability, utilization and protection.

\section{Mineralization Processes of the Potable Natural Mineral Water}

\section{Mechanisms Governing the Groundwater Chemistry in the Study Area}

The potential effects of hydrogeological, geological, hydrogeochemical and climatic factors on the evolution of groundwater chemistry have been discussed in various literature. It was generally considered that chemical constituents of groundwater exhibited an increasing tendency along the growing flow path of groundwater [49]. To investigate the mechanisms governing the groundwater chemistry in the study area, the Gibbs diagram was presented to display the main chemical components of groundwater at a glance. For this purpose, Gibbs [17] performed intensive statistical analysis on the chemical components of water from worldwide rivers, lakes and oceans. In his study, the controlling factors for groundwater chemistry were classified into three categories: rock dominance, evaporation crystallization dominance and precipitation dominance. Two individual diagrams, which were depicted based on two relations: TDS versus $\mathrm{Cl}^{-} /\left(\mathrm{Cl}^{-}+\right.$ $\left.\mathrm{HCO}_{3}{ }^{-}\right)$and TDS against $\mathrm{Na}^{+} /\left(\mathrm{Na}^{+}+\mathrm{Ca}^{2+}\right)$, were used to assess the sources of dissolved of groundwater.

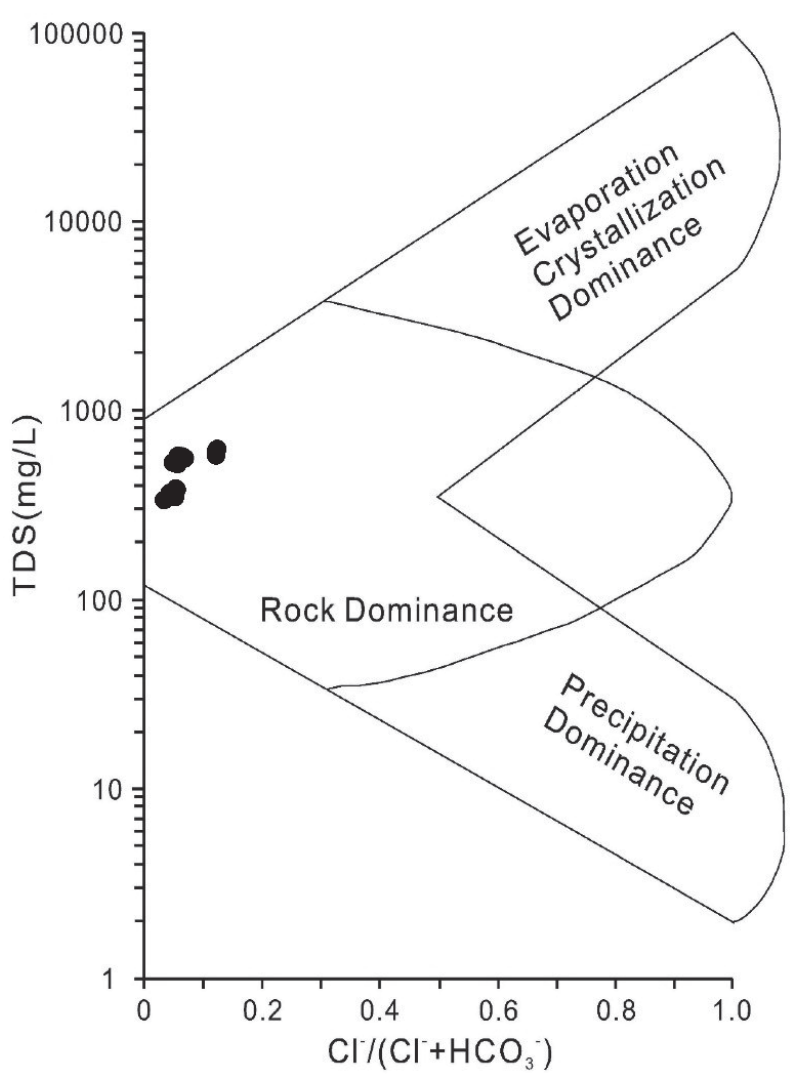

Fig. 6. Gibbs diagram of groundwater samples.

As shown in Fig. 6, all the data points are located in the area of "Rock Dominance" zone. Groundwater in the study site refers to freshwater with characteristics of Ca-rich and medium-salinity. Hence, it can be concluded that weathering of rock (rock dominance) exerts the first-order control on the groundwater chemistry in the study site. This suggests that the concentrations of major ions are heavily influenced by water-rock reactions. Compared to the evaporation-crystallization process, the rock-dominated mechanism produces freshwater with medium-salinity as evaporation causes salinity to increase.

\section{Mineralization Process of $\mathrm{H}_{2} \mathrm{SiO}_{3}$ in the Potable Natural Mineral Water}

The water-rock interactions (referred to rock dissolutions along the flow path of groundwater) are responsible for the variations of chemical compositions in groundwater of the study site. Also, the potable natural mineral water exists in the Paleogene or Neogene sandstone confined aquifer. As such, the $\mathrm{H}_{2} \mathrm{SiO}_{3}$ in the potable natural mineral water can be considered as deriving from the dissolutions of quartzes and feldspar minerals. The dissolution reactions of quartz are as follows:

$$
\mathrm{SiO}_{2}+2 \mathrm{H}_{2} \mathrm{O} \rightarrow \mathrm{H}_{4} \mathrm{SiO}_{4}
$$




$$
\mathrm{H}_{4} \mathrm{SiO}_{4} \rightarrow \mathrm{H}_{2} \mathrm{SiO}_{3}+\mathrm{H}_{2} \mathrm{O}
$$

...where $\mathrm{SiO}_{2}$ represents the quartz minerals; $\mathrm{H}_{4} \mathrm{SiO}_{4}$ is orthosilicic acid and readily decomposes to $\mathrm{H}_{2} \mathrm{SiO}_{3}$.

The feldspars minerals including orthoclase and albite, in general, are dissolved to produce kaolinite and montmorillonite under acidic condition while the main resultant is illite with the reactant of potassium ion. These reactions can be accessed as follows:

$$
\begin{gathered}
2 \mathrm{KAlSi}_{3} \mathrm{O}_{8}+2 \mathrm{H}^{+}+\mathrm{H}_{2} \mathrm{O} \rightarrow \mathrm{Al}_{2} \mathrm{Si}_{2} \mathrm{O}_{5}(\mathrm{OH})_{4} \\
+4 \mathrm{SiO}_{2}+2 \mathrm{~K}^{+}
\end{gathered}
$$

$$
\begin{gathered}
2 \mathrm{NaAlSi}_{3} \mathrm{O}_{8}+2 \mathrm{H}^{+}+\mathrm{H}_{2} \mathrm{O} \rightarrow \mathrm{Al}_{2} \mathrm{Si}_{2} \mathrm{O}_{5}(\mathrm{OH})_{4} \\
+4 \mathrm{SiO}_{2}+2 \mathrm{Na}^{+}
\end{gathered}
$$

$$
\begin{aligned}
3 \mathrm{KAlSi}_{3} \mathrm{O}_{8}+ & 2 \mathrm{H}^{+}+\mathrm{H}_{2} \mathrm{O} \rightarrow \mathrm{KAl}_{3} \mathrm{Si}_{3} \mathrm{O}_{10}(\mathrm{OH})_{2} \\
+ & 6 \mathrm{SiO}_{2}+2 \mathrm{~K}^{+}+\mathrm{H}_{2} \mathrm{O}
\end{aligned}
$$

$$
\begin{gathered}
3 \mathrm{NaAlSi}_{3} \mathrm{O}_{8}+\mathrm{K}^{+}+2 \mathrm{H}^{+}+\mathrm{H}_{2} \mathrm{O} \rightarrow \mathrm{KAl}_{3} \mathrm{Si}_{3} \mathrm{O}_{10}(\mathrm{OH})_{2} \\
+6 \mathrm{SiO}_{2}+3 \mathrm{Na}^{+}+\mathrm{H}_{2} \mathrm{O}
\end{gathered}
$$

$$
\begin{gathered}
7 \mathrm{NaAlSi}_{3} \mathrm{O}_{8}+6 \mathrm{H}^{+}+\mathrm{H}_{2} \mathrm{O} \rightarrow \\
3 \mathrm{Na}_{0.33} \mathrm{Al}_{2.33} \mathrm{Si}_{3.67} \mathrm{O}_{10}(\mathrm{OH})_{2} \\
+10 \mathrm{SiO}_{2}+6 \mathrm{Na}^{+}+\mathrm{H}_{2} \mathrm{O}
\end{gathered}
$$

...where $\mathrm{KAlSi}_{3} \mathrm{O}_{8}$ is orthoclase; $\mathrm{Al}_{2} \mathrm{Si}_{2} \mathrm{O}_{5}(\mathrm{OH})_{4}$ is kaolinite; $\mathrm{NaAlSi}_{3} \mathrm{O}_{8}$ is albite; $\mathrm{KAl}_{3} \mathrm{Si}_{3} \mathrm{O}_{10}(\mathrm{OH})_{2}$ is illite; $\mathrm{Na}_{0.33} \mathrm{Al}_{2.33} \mathrm{Si}_{3.67} \mathrm{O}_{10}(\mathrm{OH})_{2}$ is montmorillonite; $\mathrm{SiO}_{2}$ is amorphous silicon dioxide.
The spontaneity of these chemical reactions (Eqs 1-7) required to be evaluated as quartz and feldspar minerals are generally incapable of dissolved by water. In the chemical thermodynamics theory, Gibbs function can function as the basis that judges direction and limit of chemical reaction, or as the measurement of irreversibility for chemical reaction. This study, therefore, pioneered the use of the chemical thermodynamics analysis to assess the spontaneity of the groundwater hydrochemical process (i.e., water-rock reactions).

In this study, the Gibbs free energy change- $\Delta \mathrm{G}$ was referenced to determine whether these chemical reactions can happen spontaneously under the hydrochemical setting of groundwater in the study area. For a hypothetical chemical reaction $\mathrm{aA}+\mathrm{bB} \rightarrow \mathrm{cC}+\mathrm{dD}, \Delta \mathrm{G}$ values can be calculated as the following equation:

$$
\Delta \mathrm{G}=\Delta \mathrm{G}^{\mathrm{o}}+\mathrm{RT} \ln [\mathrm{C}]^{\mathrm{c}}[\mathrm{D}]^{\mathrm{d}} /[\mathrm{A}]^{\mathrm{a}}[\mathrm{B}]^{\mathrm{b}}
$$

...where $\Delta \mathrm{G}^{\circ}$ is the increment of free energy for the reaction under the temperature of $\mathrm{T}$ (thermodynamic temperature) and pressure of $100 \mathrm{kPa}$; $\mathrm{R}$ is the gas constant defined as $8.314 \mathrm{~J} /(\mathrm{K} \cdot \mathrm{mol})$.

The $\Delta \mathrm{G}^{\circ}$ exhibited in Eq. (8) can be accessed in the "Lange's Handbook of Chemistry" [50]. In this study, a value of $298.15 \mathrm{~K}$ was assigned to $\mathrm{T}$ and $\Delta \mathrm{G}^{\circ}$ values of the reactants and products in chemical reactions (Eqs. 1-7) were listed in Table 3. According to the averaging $\mathrm{PH}$ values, cation and anion concentrations of sampled groundwater, $\Delta \mathrm{G}$ values of the above chemical reactions (Eqs. 1, 3-7) were calculated and subsequently presented in Table 4.

For the dissolution reaction shown in Eq. (1), the $\Delta \mathrm{G}$ value is approximately zero and indicates that

Table 3. Summary of $\Delta$ Go values under the temperature of $298.15 \mathrm{~K}$ and pressure of $100 \mathrm{kPa}$.

\begin{tabular}{|c|c|c|c|}
\hline \multirow{2}{*}{ Reactants and products } & \multicolumn{3}{|c|}{ Thermodynamic parameters } \\
\cline { 2 - 4 } & $\Delta H^{0}(\mathrm{~kJ} / \mathrm{mol})$ & $S^{0}(\mathrm{~J} / \mathrm{K} \cdot \mathrm{mol})$ & $\Delta G^{0}(\mathrm{~kJ} / \mathrm{mol})$ \\
\hline $\mathrm{KAlSi}_{3} \mathrm{O}_{8}$ & -3967.000 & 214.200 & -3742.433 \\
\hline $\mathrm{NaAlSi}_{3} \mathrm{O}_{8}$ & -3935.115 & 207.400 & -3711.850 \\
\hline $\mathrm{Al}_{2} \mathrm{Si}_{2} \mathrm{O}_{5}(\mathrm{OH})_{4}$ & -4120.114 & 203.050 & -3799.580 \\
\hline $\mathrm{KAl}_{3} \mathrm{Si}_{3} \mathrm{O}_{10}(\mathrm{OH})_{2}$ & -5976.740 & 306.400 & -5600.904 \\
\hline $\mathrm{Na}_{0.33} \mathrm{Al}_{2.33} \mathrm{Si}_{3.67} \mathrm{O}_{10}(\mathrm{OH})_{2}$ & -5718.691 & 252.755 & -5345.986 \\
\hline $\mathrm{SiO}_{2}$ & -910.700 & 41.460 & -853.320 \\
\hline $\mathrm{H}_{2} \mathrm{O}$ & -285.830 & 69.950 & -237.190 \\
\hline $\mathrm{H}_{4} \mathrm{SiO}_{4}$ & -1460.000 & 180.000 & -1307.936 \\
\hline $\mathrm{H}^{+}$ & 0 & 0 & 0 \\
\hline $\mathrm{K}^{+}$ & -252.170 & 101.040 & -282.476 \\
\hline $\mathrm{Na}^{+}$ & -240.300 & 58.410 & -261.885 \\
\hline
\end{tabular}

Note: $\Delta H^{\circ}$ is standard molar enthalpy; $S^{\circ}$ is standard molar entropy 
Table 4 . Summary of $\Delta \mathrm{G}$ values for different chemical reactions.

\begin{tabular}{|c|c|c|c|c|c|c|}
\hline \multirow{2}{*}{$\begin{array}{c}\text { Thermodynamic } \\
\text { parameters }\end{array}$} & $\begin{array}{c}\text { Eq. (1): } \\
\text { Quartz } \rightarrow \\
\text { orthosilicic acid }\end{array}$ & $\begin{array}{c}\text { Eq. (3): } \\
\text { Orthoclase } \rightarrow \\
\text { kaolinite }\end{array}$ & $\begin{array}{c}\text { Eq. (4): } \\
\text { Albite } \rightarrow \\
\text { kaolinite }\end{array}$ & $\begin{array}{c}\text { Eq. (5): } \\
\text { Orthoclase } \rightarrow \\
\text { illite }\end{array}$ & $\begin{array}{c}\text { Eq. (6): } \\
\text { Albite } \rightarrow \\
\text { illite }\end{array}$ & $\begin{array}{c}\text { Eq. (7): } \\
\text { Albite } \rightarrow \\
\text { montmorillonite }\end{array}$ \\
\hline$\Delta G^{\circ}(\mathrm{kJ} / \mathrm{mol})$ & 19.764 & -55.756 & -75.740 & -58.477 & -88.453 & -159.518 \\
\hline$\Delta G(\mathrm{~kJ} / \mathrm{mol})$ & -0.271 & -16.885 & -16.665 & -19.606 & -19.276 & 17.708 \\
\hline
\end{tabular}

this chemical reaction is extremely nearly chemical equilibrium. It can be concluded that quartz minerals in sandstone aquifer are not possible to highly dissolve through water-rock interaction under the hydrochemical setting of the study site. As such, the mineralization process of $\mathrm{H}_{2} \mathrm{SiO}_{3}$ is not attributed to the dissolution of quartz minerals.

Moreover, dissolution reactions including orthoclasekaolinite/illite and albite-kaolinite/illite possessed $\Delta \mathrm{G}$ values less than zero. While the Gibbs free energy of the albite-montmorillonite dissolution reaction reveals an increasing tendency $(\Delta G>0)$. These findings reveal that orthoclase-kaolinite/illite and albite-kaolinite/illite can be classified as spontaneous reactions. Compared with the kaolinite, the orthoclase and albite are prone to transform into illite by the water-rock reaction. The dissolution of feldspar minerals can enrich the concentration of silicon component in water, eventually generating metasilicic acid.

Based on the chemical thermodynamics theory, the $\Delta \mathrm{G}$ can decrease substantially with an escalation of temperature, exhibiting a linearity change tendency. High temperature makes the orthoclase and albite more easily dissolved by water. Against the in-situ testing results, the temperature of groundwater in confined sandstone aquifer was measured up to $28^{\circ} \mathrm{C}$ (equal to $301.15 \mathrm{~K}$ ) and exceeded assuming a value of T-298.15 K. Meanwhile, the pressure is also an essential factor to affect the Gibbs function, where the $\Delta G$ can rise slightly due to the increasing pressure. According to the principle of effective stress, the effective geostatic stress of confined sandstone aquifer (with depth of $230 \sim 530 \mathrm{~m}$ ) in study site ranges from 2 to $5 \mathrm{MPa}$., which is higher than the pressure of $100 \mathrm{kPa}$ defined in $\Delta \mathrm{G}^{\circ}$. There is an indication that the actual $\Delta \mathrm{G}$ values of orthoclase and albite dissolution reactions are lower than the calculated $\Delta \mathrm{G}$ values in Table 4 . The orthoclase and albite, thus, have higher dissolubility under the hydrochemical setting of the study site.

Therefore, the water-rock reactions, including orthoclase-kaolinite/illite and albite-kaolinite/illite, contribute to the mineralization process of amorphous silicon dioxide in groundwater. In general, amorphous silicon dioxide is characterized by high specific surface area, abundant surface hydroxyl groups and high hydrophilicity. It, thus, shows high solubility in the water. By dissolution of the amorphous silicon dioxide, the $\mathrm{H}_{2} \mathrm{SiO}_{3}$ accumulates in groundwater. Moreover, the
$\mathrm{H}_{2} \mathrm{SiO}_{3}$ concentration will increase continuously in the groundwater of the study site because of the negative $\Delta \mathrm{G}$ of orthoclase/albite-water reactions.

The presented findings indicate that Gibbs function can provide insight into determining the origins of minerals and understanding mineralization processes of the potable natural mineral water. In previous studies, academics brought attention to using equilibrium phase diagram to judge the chemical equilibrium state of water-rock reactions, where the feldspars-water equilibrium phase diagrams were drew using the concentrations of $\mathrm{H}_{4} \mathrm{SiO}_{4}, \mathrm{~K}^{+}, \mathrm{Ca}^{2+}, \mathrm{Na}^{+}$and $\mathrm{H}^{+}$. Based on the diagrams, the dissolution-precipitate dynamic equilibrium state between groundwater and minerals such as kaolinite, montmorillonite and gibbsite can be identified. However, this method assumes that waterrock reactions are in equilibrium and the determination of the direction of water-rock reactions remains unresolved. It, therefore, is unclear how the chemical components in groundwater change under certain geological setting.

\section{Mineralization Process of Sr in Potable Natural Mineral Water}

Due to the regional hydrogeological survey, it was noted that the recharge area of the groundwater in the study site was located at the southern mountainous area in the vicinity of Zibo city (near the "A" points in Fig. 3a). The atmospheric precipitation dropped in the recharge area flows to the study area by the mean of groundwater runoff along the flow path (see Fig. 3b). It is generally recognized that there is comparatively abundant strontium carbonate $\left(\mathrm{SrCO}_{3}\right)$ in the limestone and dolomite which are the dominant bedrocks in the recharge area (see Fig. 3). The abundance values of strontium element above limestone and dolomite were measured up to $543 \times 10^{-6}$ and exceeded the averaging abundance value of strontium element $375 \times 10^{-6}$ ) in the earth's crust.

In most cases, the carbonatites can be readily dissolved by slightly acidic water infiltrating into the rock along the fissures, and lead to the escalation of a typical landscape named karst. Dissolution of the $\mathrm{SrCO}_{3}$ reacts simultaneously during the karst process and the chemical reaction can be described as follows:

$$
\mathrm{SrCO}_{3}+\mathrm{H}_{2} \mathrm{O}+\mathrm{CO}_{2} \rightarrow \mathrm{Sr}^{2+}+2 \mathrm{HCO}_{3}^{-}
$$


In the study area, the high amount of $\mathrm{Sr}$ in the potable natural mineral water is attributed to the dissolution of limestone or dolomite in the recharge area. Groundwater containing $\mathrm{Sr}$ discharge to the downgradient area (i.e., study site) along its flow path.

\section{Conclusions}

Based on the hydrochemical analysis data, groundwater in the study site is desirable for drinking according to the national standard of China. Two main groundwater types i.e., $\mathrm{Na} \cdot \mathrm{Ca} \cdot \mathrm{Mg}-\mathrm{HCO}_{3}$ and $\mathrm{Na}-\mathrm{HCO}_{3}$ type were found in the confined sandstone aquifer using Piper diagrams. Moreover, two beneficial chemical components including $\mathrm{H}_{2} \mathrm{SiO}_{3}$ and $\mathrm{Sr}$ in groundwater samples are measured up to the standard values of potable natural mineral water. Also, other index properties are in agreement with the respective standard value following the guidelines from the national standard of China. The high-quality groundwater in the study area can be regarded as the potable natural mineral water for exploitability, utilization and protection.

Chemical constituents of groundwater in the study site are governed by a series of water-rock interactions. The chemical thermodynamics analyses indicate that the main processes contributing to the abundant $\mathrm{H}_{2} \mathrm{SiO}_{3}$ in groundwater are the dissolutions of feldspar minerals (i.e. orthoclase and albite) rather than quartz minerals. In the recharge area, bedrocks are dominant limestone and dolomite which contain comparatively abundant $\mathrm{SrCO}_{3}$. The increase of $\mathrm{Sr}$ in groundwater originates from the dissolution of $\mathrm{SrCO}_{3}$ by slightly acidic water infiltrating into the rock and this chemical reaction reacts simultaneously during the karst process on carbonates.

The present study reveals the hydrochemical characteristics, water types and water quality of potable natural mineral water in Caowang town, northern China. It also pioneers using Gibbs function to identify the origins of minerals or microelements in potable natural mineral water. This study can provide insight for protecting the recharge area and ensure the quality of potable natural mineral water in the study site, thereby guiding the management of the precious groundwater resource. Considering the water quality, protection of recharge area can be helpful to escape the escalation of contaminants. It is highly recommended to exploit potable natural mineral water in deep confined aquifers (referred to Neogene and Paleogene sandstone aquifers). Also, the exploitation wells should be insulated from contaminants before making any commercialized managerial decision. Moreover, this study helps to minimize the risk of resource exploitation and gain significant economic, social and environmental benefits.

The chemical thermodynamics analysis has been demonstrated to play a role in judging the spontaneity of the water-rock reactions and assessing the mineralization process for potable natural mineral water. The groundwater whose chemistry governed by the water-rock reactions could reference the discoveries of this study to conduct the assessment of the hydrochemical process, thereby saving time and by implication costs.

\section{Acknowledgments}

Research in this paper is supported by the National Natural Science Foundation of China (grant numbers 41877239, 51379112, 51422904, 40902084 and 41772298), and Fundamental Research Fund of Shandong University (grant number 2018JC044), and Natural Science Foundation of Shandong Province (grant number JQ201513 and 2019GSF111028). The authors would like to thank the editors and reviewers for their time and effort in reviewing and improving this paper.

\section{Conflict of Interest}

The authors declare no conflict of interest.

\section{References}

1. MURAD A.A., NUAIMI H.A., HAMMADI M.A. Comprehensive assessment of water resources in the United Arab Emirates (UAE). Water Resource Management, 21(9), 1449, 2007.

2. JIANG Y., WU Y., GROVES C., YUAN D., KAMBESIS P. Natural and anthropogenic factors affecting the groundwater quality in the Nandong karst underground river system in Yunan, China. Journal of Contaminant Hydrology, 109, 49, 2009.

3. XUE Y., KONG F., LI S., ZHANG Q., QIU D., SU M., LI Z. China starts the world's hardest "Sky-High Road" project: Challenges and countermeasures for Sichuan-Tibet railway. The Innovation, 2(2), 100105, 2021.

4. XUE Y., KONG F., QIU D., SU M., ZHAO Y., ZHANG K. The classifications of water and mud/rock inrush hazard: a review and update. Bulletin of Engineering Geology and the Environment, 80, 1907, 2020.

5. ACHEAMPONG S.Y., HESS J.W. Hydrogeologic and hydrochemical framework of the shallow groundwater system in the southern Voltaian Sedimentary Basin, Ghana. Hydrogeology Journal, 6, 527, 1998.

6. GHOLAMI V., YOUSEFI Z., ROSTAMI H.Z. Modeling of groundwater salinity on the Caspian Southern Coasts. Water Resource Management, 24, 1415, 2010.

7. ARGAMASILLA M., BARBERÁ J.A., ANDREO B. Factors controlling groundwater salinization and hydrogeochemical processes in coastal aquifers from southern Spain. Science of the Total Environment, 580, 50, 2017.

8. HABIB E., LARSON B.F., NUTTLE W.K., RIVERAMONROY V.H., NELSON B.R., MESELHE E.A., TWILLEY R.R. Effect of rainfall spatial variability and sampling on salinity prediction in an estuarine system. Journal of Hydrology, 350, 56, 2008. 
9. DOGRAMACI S., SKRZYPEK G., DODSON W., GRIERSON P.F. Stable isotope and hydrochemical evolution of groundwater in the semi-arid Hamersley Basin of subtropical northwest Australia. Journal of Hydrology, 475, 281, 2012.

10. MOSTAZA-COLADO D., CARREÑO-CONDE F., RASINES-LADERO R., IEPURE S. Hydrogeochemical characterization of a shallow alluvial aquifer: 1 baseline for groundwater quality assessment and resource management. Science of the Total Environment, 639, 1110, 2018.

11. CHENINI I., KHEMIRI S. Evaluation of ground water quality using multiple linear regression and structural equation modeling. International Journal of Environment Science and Technology, 6 (3), 509, 2009.

12. JIA H., QIAN H., ZHENG L., FENG W., WANG H., GAO Y. Alterations to groundwater chemistry due to modern water transfer for irrigation over decades. Science of The Total Environment, 717, 137170, 2020.

13. MARGHADE D., MALPE D.B., SUBBARAO N., SUNITHA B. Geochemical assessment of fluoride enriched groundwater and health implications from a part of Yavtmal District, India. Human and Ecological Risk Assessment: An International Journal, 26 (3), 673, 2020.

14. PIPER A.M. A graphic procedure in the geochemical interpretation of water analysis. Transactions American Geophysical Union, 25, 914, 1944.

15. DUROV S.A. Natural waters and graphic representation of their compositions. Dokl Akad Nauk SSSR, 59, 87, 1948.

16. CHADHA D.K. A proposed new diagram for geochemical classification of natural waters and interpretation of chemical data. Hydrogeology Journal, 7, 431-439, 1999.

17. GIBBS R.J. Mechanisms controlling world water chemistry. Science, 170, 1088-1090, 1970.

18. MARANDI A., SHAND P. Groundwater chemistry and the Gibbs Diagram. Applied Geochemistry, 97, 209-212, 2018.

19. NGUYEN T.T., KAWAMURA A., TONG T.N., NAKAGAWA N., AMAGUCHI H., GILBUENA JR R. Clustering spatio-seasonal hydrogeochemical data using self-organizing maps for groundwater quality assessment in the Red River Delta, Vietnam. Journal of Hydrology, 522, 661-673, 2015.

20. RAFIQUE T., NASEEM S., OZSVATH D., HUSSAIN R., BHANGER M.I., USMANI T.H. Geochemical controls of high fluoride groundwater in Umarkot sub-district, Thar Desert, Pakistan. Science of the Total Environment, 530, 271-278, 2015.

21. YANG Q., ZHANG J., WANG Y., FANG Y., MARTÍN J.D. Multivariate statistical analysis of hydrochemical data for shallow ground water quality factor identification in a coastal aquifer. Polish Journal of Environmental Studies, 24(2), 769-776, 2015.

22. JØRGENSEN N.O., BANOENG-YAKUBO B.K. Environmental isotopes $\left({ }^{18} \mathrm{O},{ }^{2} \mathrm{H}\right.$, and $\left.{ }^{87} \mathrm{Sr} /{ }^{86} \mathrm{Sr}\right)$ as a tool in groundwater investigations in the Keta Basin, Ghana. Hydrogeology Journal, 9, 190-201, 2001.

23. CARTWRIGHT I., HALL S., TWEED S., LEBLANC M. Geochemical and isotopic constraints on the interaction between saline lakes and groundwater in southeast Australia. Hydrogeology Journal, 17, 1991-2004, 2009.

24. MEEK K., DERRY L., SPARKS J., CATHLES L. ${ }^{87} \mathrm{Sr} /{ }^{86} \mathrm{Sr}$, $\mathrm{Ca} / \mathrm{Sr}$, and $\mathrm{Ge} / \mathrm{Si}$ ratios as tracers of solute sources and biogeochemical cycling at a temperate forested shale catchment, central Pennsylvania, USA. Chemical Geology, 445, 84-102, 2016.
25. ANORNU G., GIBRILlA A., ADOMAKO D. Tracking nitrate sources in groundwater and associated health risk for rural communities in the White Volta River basin of Ghana using isotopic approach $\left(\delta^{15} \mathrm{~N}, \delta^{18} \mathrm{ONO}_{3}\right.$ and $\left.{ }^{3} \mathrm{H}\right)$. Science of the total environment, 603, 687, 2017.

26. SZYNKIEWICZ A., OLICHWER T., TARKA R. Delineation of groundwater provenance in Arctic environment using isotopic compositions of water and sulphate. Journal of Hydrology, 580, 124232, 2020.

27. ORTEGA-GUERRERO A. Origin and geochemical evolution of groundwater in a closed-basin clayey aquitard, Northern Mexico. Journal of hydrology, 284 (1-4), 26, 2003.

28. HELSTRUP H., JØRGENSEN N.O., BANOENGYAKUBO B. Investigation of hydrochemical characteristics of groundwater from Cretaceous-Eocene limestone aquifer in southern Ghana and southern Togo using hierarchical cluster analysis. Hydrogeology Journal, 15, 977, 2007.

29. NASSERY H.R., KAYHOMAYOON Z. Source of salinity in the groundwater of Lenjanat Plain, Isfahan, Iran. Environmental Earth Science, 68 (2), 413, 2013.

30. LEDESMA-RUIZ R., PASTÉN-ZAPATA E., PARRA R., HARTER T., MAHLKNECHT J. Investigation of the geochemical evolution of groundwater under agricultural land: a case study in northeastern Mexico. Journal of Hydrology, 521, 410, 2015.

31. LIU P., HOTH N., DREBENSTEDT C., SUN Y., XU Z. Hydro-geochemical paths of multi-layer groundwater system in coal mining regions - Using multivariate statistics and geochemical modeling approaches. Science of the Total Environment, 601, 1, 2017.

32. DUNNETTE D.A. A geographically variable water quality index used in Oregon. Journal Water Pollution Control Federation, 51 (1), 53, 1979.

33. ŞENER Ş., ŞENER E., DAVRAZ A. Evaluation of water quality using water quality index (WQI) method and GIS in Aksu River (SW-Turkey). Science of the Total Environment, 584, 131, 2017.

34. ADIMALLA N., LI P., VENKATAYOGI S. Hydrogeochemical evaluation of groundwater quality for drinking and irrigation purposes and integrated interpretation with water quality index studies. Environmental Processes, 5 (2), 363, 2018.

35. VASANTHAVIGAR M., SRINIVASAMOORTHY K., VIJAYARAGAVAN K., GANTHI R.R., CHIDAMBARAM S., ANANDHAN P., MANIVANNAN R., VASUDEVAN S. Application of water quality index for groundwater quality assessment: Thirumanimuttar sub-basin, India. Environmental Monitoring and Assessment, 171, 595, 2010.

36. BENNETTS D.A., WEBB J.A., STONE D.J.M., HILL D.M. Understanding the salinisation process for groundwater in an area of south-eastern Australia, using hydrochemical and isotopic evidence. Journal of Hydrology, 323 (1-4), 178, 2006.

37. MACHIWAL D., JHA M.K. Identifying sources of groundwater contamination in a hard-rock aquifer system using multivariate statistical analyses and GIS-based geostatistical modeling techniques. Journal of Hydrology: Regional Studies, 4, 80, 2015.

38. KAWO N.S., KARUPPANNAN S. Groundwater quality assessment using water quality index and GIS technique in Modjo River Basin, central Ethiopia. Journal of African Earth Sciences, 147, 300, 2018. 
39. RABEIY R.E. Assessment and modeling of groundwater quality using WQI and GIS in Upper Egypt area. Environmental Science and Pollution Research, 25 (31), 30808, 2018.

40. GUIAMEL I.A., LEE H.S. Watershed modelling of the Mindanao River Basin in the Philippines using the SWAT for water resource management. Civil Engineering Journal, 6 (4), 626, 2020.

41. BELKHIRI L., NARANY T.S. Using multivariate statistical analysis, geostatistical techniques and structural equation modeling to identify spatial variability of groundwater quality. Water Resources Management, 29 (6), 2073, 2015.

42. BURTON T.G., RIFAI H.S., HILDENBRAND Z.L., CARLTON JR D.D., FONTENOT B.E., SCHUG K.A. Elucidating hydraulic fracturing impacts on groundwater quality using a regional geospatial statistical modeling approach. Science of the Total Environment, 545, 114, 2016.

43. HOURIA B., MAHDI, K., ZOHRA, T.F. Hydrochemical characterisation of groundwater quality: Merdja plain (Tebessa town, Algeria). Civil Engineering Journal, 6 (2), 318, 2020.

44. XUE Y., KONG F., LI S., QIU D., SU M., LI Z., ZHOU, B. Water and mud inrush hazard in underground engineering:
Genesis, evolution and prevention. Tunnelling and Underground Space Technology, 114, 103987, 2021.

45. FAZELABDOLABADI B., GOLESTAN M.H. Towards Bayesian Quantification of Permeability in Micro-scale Porous Structures-The Database of Micro Networks. HighTech and Innovation Journal, 1 (4), 148, 2020.

46. NHFPC (National Health and Family Planning Commission of China)., CFDA (China Food and Drug Administration). Standard Methods for the Analysis of Potable Natural Mineral Water; Beijing, 2016.

47. MOHC (Ministry of health of China)., SAC (Standardization Administration of China). Standards for Potable Water Quality; Beijing, 2006.

48. AQSIQ (General Administration of Quality supervision, Inspection and Quarantine of China)., SAC (Standardization Administration of China). Standards for Potable Natural Mineral Water; Beijing, 2008.

49. FIJANI E., MOGHADDAM A.A., TSAI F.T.C., TAYFUR G. Analysis and assessment of hydrochemical characteristics of Maragheh-Bonab plain aquifer, northwest of Iran. Water Resource Management, 31 (3), 765, 2017.

50. SPEIGHT J.G. Lange's handbook of chemistry, $16^{\text {th }}$ Ed; RR Donnelley, Chicago, 2004. 